\title{
Specialised education makes a difference in preschool teachers' knowledge bases in the teaching of mathematics and science: A case of Botswana and Sweden
}

\begin{tabular}{|c|c|}
\hline \multicolumn{2}{|c|}{$\begin{array}{l}\text { Authors: } \\
\text { Kabita Bose }{ }^{1} \\
\text { Kerstin Bäckman }\end{array}$} \\
\hline \multicolumn{2}{|c|}{$\begin{array}{l}\text { Affiliations: } \\
{ }^{1} \text { Department of Primary } \\
\text { Education, Faculty of } \\
\text { Education, University } \\
\text { of Botswana, Gaborone, } \\
\text { Botswana }\end{array}$} \\
\hline \multicolumn{2}{|c|}{$\begin{array}{l}{ }^{2} \text { Department of Educational } \\
\text { Science, Faculty of Education } \\
\text { and Business Studies, } \\
\text { University of Gävle, } \\
\text { Gävle, Sweden }\end{array}$} \\
\hline \multicolumn{2}{|c|}{$\begin{array}{l}\text { Corresponding author: } \\
\text { Kerstin Bäckman, } \\
\text { kerstin.backman@hig.se }\end{array}$} \\
\hline \multicolumn{2}{|c|}{$\begin{array}{l}\text { Dates: } \\
\text { Received: } 07 \text { Oct. } 2019 \\
\text { Accepted: } 09 \text { Sept. } 2020 \\
\text { Published: } 08 \text { Dec. } 2020\end{array}$} \\
\hline \multicolumn{2}{|c|}{$\begin{array}{l}\text { How to cite this article: } \\
\text { Bose, K. \& Bäckman, K., } \\
2020, \text { 'Specialised education } \\
\text { makes a difference in } \\
\text { preschool teachers' } \\
\text { knowledge bases in the } \\
\text { teaching of mathematics and } \\
\text { science: A case of Botswana } \\
\text { and Sweden', South African } \\
\text { Journal of Childhood } \\
\text { Education } 10(1), \text { a815. } \\
\text { https://doi.org/10.4102/ } \\
\text { sajce.v10i1.815 }\end{array}$} \\
\hline \multicolumn{2}{|c|}{$\begin{array}{l}\text { Copyright: } \\
\text { (C) 2020. The Authors. } \\
\text { Licensee: AOSIS. This } \\
\text { is licensed under the } \\
\text { Creative Commons } \\
\text { Attribution License. }\end{array}$} \\
\hline \multirow[b]{2}{*}{ Read online: } & \\
\hline & $\begin{array}{l}\text { Scan this QR } \\
\text { code with your } \\
\text { smart phone or } \\
\text { mobile device } \\
\text { to read online. }\end{array}$ \\
\hline
\end{tabular}

Background: Education in mathematics and science is important at all school levels and should ideally start in the preschool, which implies that preschool teachers should have an adequate knowledge base in these subjects.

Aim: This study aimed to investigate preschool teachers' knowledge bases, including their subject matter knowledge (SMK) and pedagogical content knowledge (PCK) in mathematics and science.

Setting: The study presents an account of preschool teachers' knowledge bases in mathematics and science in Botswana and Sweden and how they influence their teaching choices and strategies.

Methods: A pragmatic paradigm with a survey design and a mixed-methods mode with quantitative and qualitative approaches was used. Using a purposive sampling procedure, 64 preschool teachers from Botswana and 67 from Sweden participated in the study. Questionnaires and observation schedules were used to collect the data.

Results: The findings showed that the Swedish preschool teachers had SMK and PCK in the two subjects. The Botswana teachers had SMK but lacked PCK. The early childhood educated preschool teachers from Sweden with developed PCK highlighted the daily routine situations as teaching or learning situations, whereas the primary school teachers from Botswana had SMK but found it difficult to teach at the preschool level.

Conclusion: The preschool teachers' knowledge bases included a play-based approach and knowledge about didactic considerations in spontaneous situations that made them teachable. The findings also showed the importance of a framework for specialised and professional early childhood education (ECE) training and acquiring SMK and PCK that contributed to the preschool teachers' knowledge bases and practices in their teaching of mathematics and science. Early childhood education teachers' educational experiences, their specialised and professional training profiles and the knowledge they acquired determined their knowledge bases and the SMK and PCK that minimised the constraints and challenges faced by them in the teaching of mathematics and science in ECE classrooms.

Keywords: Botswana; Sweden; early childhood education; mathematics; pedagogical content knowledge; science; subject matter knowledge; teachers' knowledge bases.

\section{Introduction}

Pupils at all school levels in Sweden, a developed country, generally show a lack of interest in mathematics and science, perhaps because of a fear of not being able to cope with these particular subjects. In Botswana, a developing country, pupils also exhibit a lack of interest in mathematics and science and perform poorly at primary, secondary and tertiary levels (ed. Mathangwane 2011). In Sweden and Botswana, reports like Programme for International Student Assessment (PISA) and Trends in International Mathematics and Science Study (TIMSS) have shown a similar trend. However, in Sweden - and particularly in Swedish preschools - major efforts have been made to help children to develop a greater interest in mathematics and science by means of everyday activities (The Swedish National Agency for Education 2010, 2018) and stronger curricula in these subjects. The TIMSS 2015 (The Swedish National Agency for Education 2016) and PISA reports (OECD 2018) now show that pupils in Sweden have improved their results in 
both these subjects. Botswana, on the other hand, still needs to work harder in this regard (ed. Mathangwane 2011; Republic of Botswana 2015a, 2015b).

As mathematics and science play a crucial role in our lives, the learning and understanding of these subjects and their concepts are the responsibility of all education stakeholders, including the physical and human resources and the school administration, who are accountable for the teaching-learning processes in schools (Brenneman, Stevenson-Boyd \& Frede 2009, 2016; Essa 2013).

A collaborative study of teachers' teaching and learning processes in mathematics and science in Botswana (Gaborone) and Sweden (Gavle), funded by the Swedish International Development Cooperation Agency (SIDA) and Office of Research and Development (ORD), University of Botswana (Research Project no.: R955 ECC\&E), was conducted with a view to acquire an in-depth understanding across all the school levels. This part of the project aimed to investigate preschool teachers' professional training and their knowledge bases in the teaching of mathematics and science and provide alternative measures to ensure adequate support. In this article, the focus is on the studied preschool teachers ${ }^{\prime 1}$ professional training and knowledge bases in relation to the teaching of mathematics and science in preschools in Gaborone and Gavle.

\section{Mathematics and science teaching in preschools}

The learning and understanding of mathematical and scientific concepts are crucial (Chesloff 2013). Teachers should therefore try to make the teaching simple, attractive and engaging in the classroom and provide preschool children with environments and opportunities that would enable them to develop the necessary skills and create content knowledge (CK) (Chesloff 2013), whilst they are still at an impressionable and receptive age (Campbell et al. 2018; Chesloff 2013; Hunting, Mousley \& Perry 2012). Teachers need knowledge in order to give children opportunities to develop their knowledge, curiosity, creativity, critical thinking and collaborative problem-solving skills (Chesloff 2013; Clements \& Sarama 2009; Fleer, Gomes \& March 2014; Klibanoff et al. 2006; Sylva et al. 2010; Wood \& Hedges 2016).

\section{Knowledge about children's experiences of content}

Children enter preschools with a range of concepts that have been gathered from their informal experiences and through active explorations of their environments in ways that help them to learn and construct their own knowledge by doing and discovering (Essa 2013; Fu 2010). In order for the mathematics and science content to make sense to young children, the teacher needs to relate to the context

1.In Botswana, the teachers in ECE are called teachers, but in Sweden they are called preschool teachers. For the sake of simplicity, in this study, we have chosen to use the term preschool teachers for all teachers involved in ECE and, more specifically, with regard to the preschool. (the physical preschool learning environment, the children and the teachers), theoretical concepts, incidences and real-life experiences (Fleer 2014, 2015; Hedges \& Cullen 2005a; Van Oers 2010). According to Wood and Hedges (2016), preschool teachers should always be actively engaged with children's thinking, build on the children's experiences and concepts to create a learning environment and provide the necessary understanding (Essa 2013; Tippet \& Milford 2017). Seitz (2008) highlights documentation both as a didactic strategy and a way of making children's experiences visible. Activities relating to the processes of inquiry, discovery, stimulation and encouragement should be provided in preschools for the development of knowledge, logical thinking and reasoning. The provision of information and activities that require problem-solving and decisionmaking needs to be emphasised, rather than the memorising of isolated mathematical and scientific concepts (Gallenstein 2004; Moomaw 2011). The authors also stress that teachers need to cultivate children's curiosity and interest by means of classroom activities, preferably through play and by using hands-on materials to believe in and see things happen. As mathematics and science are not intuitive, the teaching and learning methods need to be carefully chosen by the teachers.

\section{Engaging environment and curriculum knowledge}

According to Garbett (2003), preschool teachers need to plan, support and guide children in their learning of mathematical and scientific concepts by using a variety of teaching strategies in an environment that encourages learning through social relationships and play. Wood and Hedges (2016) emphasise an environment that facilitates and extends children's learning in terms of the holistic nature of the EC curriculum, rather than using traditional teacher-centred methods. MacDonald, Huser and Sikder (2019) stress the importance of preschool teachers' subject knowledge in order for them to actively participate in and facilitate the mastery of concepts in an interesting, easy and enjoyable way with the children. Clements and Sarama (2009), Darling-Hammond (2000), Fu (2010), Garbett (2003), Kallery and Psillos (2001) and MacDonald et al. (2019) highlight the use of a specific context and content and endorse working with a developmentally appropriate curriculum that refers to the specific region and the children's and their families' backgrounds.

Research indicates that preschool teachers need to understand how children learn and what they are capable of learning (Campbell et al. 2018; Fleer 2014, 2015; Van Oers 2010; Vogt et al. 2018). They should also have sufficient CK and knowledge about children's experiences in different subject areas so that they can provide a challenging and stimulating environment for the development of young children's mathematical and scientific skills and technological competences. Studies further reveal that preschool teachers should be flexible and reflect on their 
own choices of content whilst critically analysing and evaluating them (Cohrssen et al. 2013).

\section{A play-based teaching approach}

Researchers have shown that the use of a play-based approach in the learning and teaching of mathematics and science in early childhood education (ECE) is crucial in that it can prepare young children for future education (Campbell et al. 2018; Fleer 2014, 2015; Van Oers 2010; Vogt et al. 2018). They have also emphasised that, through play, teachers should try and provide the most enriching environment for the learning of concepts and help children to take a keen interest in them whilst absorbing and exploring the physical world and acquiring the essence of scientific and mathematical understanding. Gasteiger et al. (2020) argue that teaching subjects like mathematics in early childhood needs teachers with knowledge and competences that differ from the skills needed in other subjects. Moreover, other researchers have emphasised that teaching in the preschool means being aware of mathematics and science in everyday situations and turn them into learning situations (Van Oers 2010).

\section{Preschool teachers' attitudes to and competences in mathematics and science}

Against the above background, the preparation of preschool teachers is critical and informed investment in that direction is necessary. As teachers' beliefs, knowledge and pedagogies affect their teaching, there is a need for educational practices, trajectories and educator capacities (which support teachers' professional development) when teaching mathematics and science in the preschool (MacDonald et al. 2019; Murphy et al. 2018). Ideally, preschool teachers' knowledge and attitudes begin with self-perceptions of their own competencies and skills in mathematics and science, which, in turn, affect how they design their educational practices (Aldemir \& Kermani 2017; Hedges \& Cullen 2005a, 2005b). According to Piasta, Pelatti and Miller (2014), the duration of mathematics and science activities in classrooms and essential types of experiences in ECE vary depending on the teachers' backgrounds, years of experience and levels of education. Cassidy and Buell (1995) conducted a study in India with 40 kindergarten teachers and found that the classrooms with scholarship teachers who had attended 12-20 credit hours of coursework made significant gains in the EC environment rating scales (ECERS), the infant-toddler environment rating scales (ITERS) and the teacher belief scale. They even prepared their classroom environments in more developmentally appropriate ways than their counterparts who had not attended ECE courses.

Another study carried out in England (Wood \& Bennett 2000) found that teachers with theoretical knowledge reflected on their practices, changed or re-aligned their theories to practice-based contexts and learned about their own teaching. These teachers enhanced their pedagogical content knowledge (PCK) by means of didactical reflections, scaffolding, co-constructing, standing back or providing children with guidance. They interacted and thought about the children's interests and levels of understanding and based their teaching strategies on the children's everyday life experiences and interests and their own professional ECE training.

\section{Conceptual framework}

It is evident that preschool teachers need to have a sound knowledge base and an awareness of children's interests, earlier understandings, curiosity, skills and characteristics to teach mathematics and science to young children and combine the daily activities with the curriculum goals and their teaching strategies (Clements \& Sarama 2009; Fleer et al. 2014). This knowledge base includes subject matter knowledge (SMK) of the content, concepts, pedagogy and the instructional strategies that are used to teaching different subjects in the classroom (Grossman 1990; Smith 1999). Knowledge base also refers to PCK, which is an amalgamation of the content and pedagogy that are the teachers' special forms of professional understanding (Fernandez 2014; Shulman 1986a, 2015). Pedagogical content knowledge emphasises the contextual knowledge about the curriculum, the learning environment, children's experiences, the daily activities and the pedagogical and didactical strategies that are used in the classroom. Subject matter knowledge often influences what and how teachers teach, whereas PCK grows in the daily activities and the teaching. Teachers with a developed PCK have an integrated knowledge of theory and practice. Grossman's (1990) model of teachers' knowledge bases (Figure 1) emphasises PCK as being at the core of the interaction with SMK, general pedagogical knowledge (GPK) and CK.

In this model, PCK is seen as the transformation of pedagogical knowledge, the context and the specific content. General pedagogical knowledge refers to beliefs about learning and learners, as well as knowledge about the general principles of instruction. The model includes the teaching purposes, knowledge about the pupils' understanding, curricular knowledge and knowledge about instructional strategies, all of which influence and are influenced by GPK, SMK and CK. It also represents the hierarchy of the knowledge and the relationship between other kinds of knowledge.

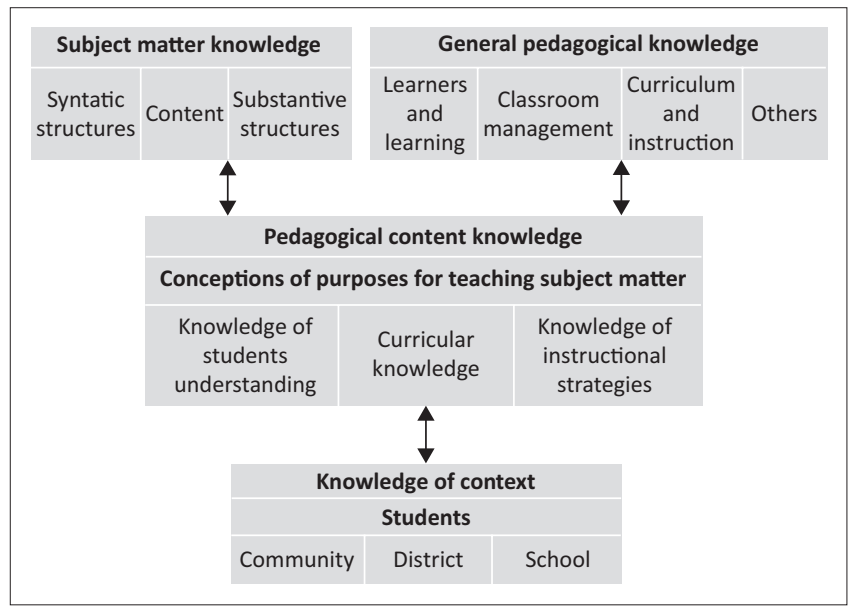

Source: Adapted from Grossman, P., 1990, The making of a teacher: Teacher knowledge and teacher education, Teachers College Press, Teachers College, Columbia University, New York, NY. FIGURE 1: Grossman's model of teacher knowledge. 
Teaching mathematics and science to preschool children involves changing the relevant SMK into a form that is comprehensible to them (Lee 2017; McCray 2008; McCray \& Chen 2012). Pedagogical content knowledge is thus very important in preschool children's learning processes as it can change high-level instructional strategies into a child's level of understanding. This article is guided by Grossman's model of teachers' knowledge bases and aims to assess the knowledge bases, PCK and SMK of the selected preschool teachers in Botswana (Gaborone) and Sweden (Gavle), and in this way highlight their classroom practices and how they help young children to develop an interest in and learn about mathematics and science.

\section{Aim and objectives}

The study aimed to investigate preschool teachers' knowledge bases, including their SMK and PCK, in mathematics and science. The objectives of the study were:

- to assess the knowledge bases of the selected preschool teachers from Sweden (Gavle) and Botswana (Gaborone) in the teaching of mathematics and science

- to determine the selected preschool teachers' PCK and SMK in Sweden (Gavle) and Botswana (Gaborone) in the teaching of mathematics and science.

\section{Research design and method}

Conducting internationally comparative studies poses several challenges, mainly because of differences in educational, cultural and social systems between countries. The researchers agreed to carry out a case study using both quantitative and qualitative methods (Cohen, Manion \& Morrison 2011) in the design. The study, with its mixedmethod mode, took a pragmatic, paradigm approach and used quantitative and qualitative methods that addressed the research objectives, viewed the mixed-method approach as a link, adopted data collection strategies in a concurrent and chronological manner and provided flexibility in the analysis (Creswell 2003; Tashakkori \& Teddlie 2009; Wiersma \& Jurs 2009).

A survey research design was used because it facilitated the data collection from different urban and semi-urban areas in and around Gaborone and Gavle. The data focused on preschool teachers' knowledge bases, including their PCK and SMK, and how they designed and carried out the teaching of mathematics and science. Classroom observations and focus group interviews were also carried out, and qualitative data were collected. A purposive sampling technique was adopted for determining a sample.

\section{Participants or sample}

Before referring to the sample, the researchers would like to briefly present the background of the two locations in which this study was conducted.
In Botswana, $10 \%$ of the population of 2 million people live in the capital city of Gaborone. Until recently, preschool education in the form of a non-compulsory ECE programme was offered by commercial enterprises, independent childcare providers and community and faith-based programmes with their own curricula and staffing policies. In 2015, the government introduced a 2-year preschool programme and reception classes for children aged between 4.5 and 5.5 years in $72 \%(n=543)$ of the country's public or government primary schools, and intends to cover the remaining 28\% ( $n=218$ ) by 2020 (Republic of Botswana 2011, 2015a). A preschool curriculum was introduced in 2015 (Republic of Botswana 2015b). However, there is a scarcity of ECE-trained teachers and approved, accredited ECE teacher training programmes in Botswana, both in the public and private sectors. Although Setswana is the national language, English is an official language and the medium of instruction in private pre-primary and primary schools (Republic of Botswana 2015b).

Gavle is located in the middle of Sweden, a Scandinavian country in Northern Europe. The official language is Swedish and is spoken by most of the country's 10 million inhabitants. Sweden started day care centres and preschools in the 1950s and within 10 years a childcare system was established at the state and municipal levels, with the social authorities being responsible for preschool education (Vallberg 2006). Childcare is now every child's and every parent's right. Most children in Sweden attend preschool, which provides a stimulating environment and enables parents to combine parenthood with work or study. Here, the preschool is a voluntary school form for children aged between 1 and 5 years of age. When children turn six, they attend a mandatory preschool class. Preschools can be private or run by the municipality and cover the same national preschool curriculum.

The study objects were preschools and preschool teachers in different parts of Gaborone and Gavle. The capital city of Gaborone was chosen because almost 15\% of the total number of preschools are situated there. The remaining preschools are scattered throughout the country's other districts (17 administrative districts, 10 rural districts and urban districts, administered by 16 local authorities (district councils, city councils or town councils). The choice of private preschools was also deliberate, as until 2014 preschool education was mainly offered by Englishspeaking private enterprises and independent childcare providers with their own curricula and staffing policies. The researchers thus selected the private, English-speaking preschools that had been established for some years and were expected to be practising normal preschool activities.

Thus, in Gaborone, 100 preschool teachers from 15 private, English-speaking and medium-sized preschools were selected: two teachers from 50 preschool classes (although 
some preschools had only one and others had five teachers). However, of these, only 64 preschool teachers returned the questionnaire for data analysis.

Gavle, together with the surrounding area, was chosen as an example of a representative area in central Sweden, with a preschool teacher programme at the university and a developed network of active preschool teachers. In Gavle, 67 preschool teachers responded to the questionnaire. In addition to the questionnaire, classroom observations and focus group interviews were carried out.

\section{Demographic data}

In Gaborone, all of the teachers were women, 31\% were between 26 and 35 years of age and 38\% were between 36 and 45 years of age. Only $14 \%$ of the teachers had received formal or professional training in ECE and had a certificate or diploma in ECE (Figure 2). All these teachers were English-speaking foreign nationals. The remaining $86 \%$ of the preschool teachers were trained as primary school teachers in mathematics, science or other subject areas, and were English-speaking Motswana (citizens of Botswana). Out of these primary school teachers, 5\% had undergraduate degree qualifications, 31\% had diplomas, $44 \%$ had teaching certificates and $13 \%$ had Standard 7 , Junior Secondary (equivalent of grade/standard 10) or Form 5 (equivalent of grade/standard 12) passes.

All 67 of the practising Swedish preschool teachers returned the questionnaire. Moreover, they all had undergone a three and a half-year-long formal or professional preschool teacher education training. Some (28\%) preschool teachers in this study had attended additional short courses in mathematics, a few others (13\%) had attended additional short courses in science (9\%) and $6 \%$ had attended short courses in both mathematics and science in addition to the preschool teacher education or ECE training (Figure 2).

\section{Research process and instruments}

Questionnaires and observation schedules were used as research instruments in both countries and were adapted contextually. The questions were in English in Gaborone and in Swedish in Gavle. The questionnaires consisted of

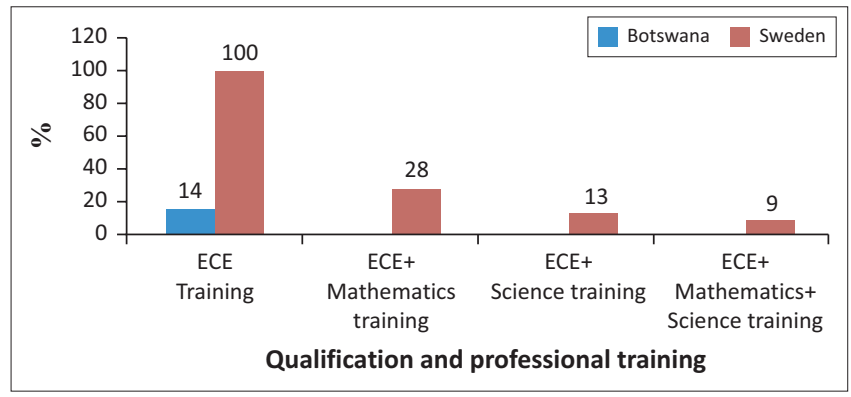

ECE, early childhood education.

FIGURE 2: Qualifications and early childhood education training. closed- and open-ended questions and covered issues relating to the teachers' formal or professional training in ECE and their knowledge bases. Classroom observations were also conducted for concurrent triangulation purposes. The researcher in Gaborone used research assistants (RAs) trained in a workshop prior to the fieldwork to administer the instruments. In Gavle, the questionnaires were uploaded to a website connected to a Swedish preschool teachers' network in a region in the middle of Sweden.

The research instruments were piloted and tested ${ }^{2}$ for their validity and reliability in four preschools from the selected sample (which did not form part of the study). Statistical Package for Social Sciences (SPSS, version 24) and Microsoft Excel were used for the quantitative analysis. The descriptive results are presented in percentages with the aid of frequency tables and graphs. Qualitative thematic measures and categories were used to analyse the qualitative data and compare the participants' verbatim statements. All the qualitative data obtained from the open-ended questions and observations were transcribed and coded for analysis. The qualitative and quantitative data were compared and are presented in the results section.

\section{Ethical consideration}

As the project was funded by SIDA and ORD (Research Project no.: R955 ECC \& E), appropriate measures were taken to seek approval to conduct the research in the selected preschools from the certified authorities. In Gaborone (Botswana), for ethical reasons and prior to the fieldwork, the researchers obtained approval from the Ministry of Education to conduct the study and written consent from the participants. Confidentiality and anonymity of the participants throughout the study were also ensured. In Gavle (Sweden), the research followed the research ethics guidelines for the social sciences in Sweden (codex.vr.se) and met the necessary requirements for information, consent, confidentiality and the use of material.

\section{Results}

This section presents the results of the preschool teachers' knowledge bases, their didactical considerations and the pedagogical practices they adopted.

\section{The preschool teachers' knowledge bases}

Table 1 shows that the teachers in Gaborone (71\%) had SMK of the conventional and contemporary mathematical and scientific concepts but lacked PCK. Their scores in the PCK-related items ranged from $30 \%$ to $57 \%$ : concept handling in preschools (57\%), children's understanding (55\%), developmentally appropriate practices $(42 \%)$, documentation of children's mathematics and science experiences (30\%), what children should learn (55\%) and knowledge about the different stages of the development of young children (64\%).

2.Three preschool teachers from Gaborone were given the questionnaire, made corrections and then administered the whole sample. 
TABLE 1: The preschool teachers' knowledge bases.

\begin{tabular}{lcc}
\hline Knowledge of & $\begin{array}{c}\text { Botswana } \\
\text { teachers (\%) }\end{array}$ & $\begin{array}{c}\text { Swedish } \\
\text { teachers (\%) }\end{array}$ \\
\hline Mathematics \& Science concepts & 71 & 69 \\
Concept handling & 57 & 75 \\
Children's understanding & 55 & 74 \\
Developmentally appropriate practices & 42 & 76 \\
Documentation of children's experiences & 30 & 58 \\
What children should learn & 55 & 74 \\
Stages of development of young children & 64 & 71 \\
\hline
\end{tabular}

In Gavle, 69\% had SMK of the mathematics and science content, which was similar to that of their Botswana counterparts, whilst their PCK ranged from 58\% to 76\% (see Table 1). In items such as knowledge of concept handling (75\%), children's understanding (74\%), developmentally appropriate practices (76\%), documentation of children's experiences (58\%) and what children should learn (74\%), they scored much higher than the teachers in Gaborone. In their knowledge about stages of development of young children $(71 \%)$, they were close to their counterparts in Gaborone. In brief, the main difference between the two groups of teachers was in their PCK.

Most of the teachers in Gaborone did not use documentation as a strategy, perhaps because they were not familiar with the benefits of documentation in the preschool. The qualitative data showed that these teachers were reasonably knowledgeable about children's developmental stages, growth and learning patterns, the basics of early childhood development and care and safety measures. They valued skills like simplifying mathematical and scientific concepts at the preschool level and knew about multiple methods of teaching at this level. Even though they failed to practise these skills and methods, perhaps because of a lack of ECE training, they were willing to acquire them in order to function better in the classroom and improve the teachinglearning process.

In contrast, $58 \%$ of the preschool teachers from Gavle documented children's classroom experiences and activities in order to gain insights into the children's experiences and thinking and how they could sharpen the children's learning. The qualitative data also showed that these preschool teachers emphasised the use of observation schedules, periodical reports/records, files, portfolios, pictures and videos for documenting the children's experiences and learning processes. The qualitative data further showed that the preschool teachers regarded knowledge about general pedagogy and didactics and the children's varied experiences as very important for preschool teaching. The practical knowledge that the preschool teachers gained whilst working with the children was based on the children's own experiences or interests. The preschool teachers highlighted the use of everyday life activities such as eating, getting dressed and other routine tasks that spontaneously took place in the preschool as opportunities to teach the various concepts involved in the teaching or learning situations. They also referred to the children as 'co-scientists', meaning that the children could explore and discover things together with other children as well as with the teachers.

To summarise, the findings show that the participants' knowledge bases should include a strong SMK and that their PCK should include a play-based approach and knowledge about making didactic choices in the teaching activities.

\section{Discussion}

The two cases in this study have differences related to educational, cultural, social and political issues and similarities when it comes to the importance of preschool teachers' SMK. Another similarity between the cases is the teachers' attitudes towards teaching. The participants highlight the use of a play-based approach along with knowledge about multiple methods of teaching in the preschool. This is in line with research on play-based education in the preschool (Campbell et al. 2018; Fleer 2014, 2015; Van Oers 2010; Vogt et al. 2018).

The key findings of the current study are the following: (1) preschool teachers' knowledge bases include a playbased approach, knowledge about didactic considerations and how to make use of spontaneous situations as teachable moments and (2) professional ECE training for preschool teachers is crucial for the development of their knowledge bases, SMK and PCK when it comes to the teaching of mathematics and science. In the study, one-third of the preschool teachers from Gavle and Gaborone lacked SMK. Research has highlighted the importance of ECE teachers' deep subject knowledge in early childhood teaching for challenging and extending children's learning (Chesloff 2013; Clements \& Sarama 2009; Hedges \& Cullen 2005a, 2005b; Klibanoff et al. 2006; Siraj-Blatchford et al. 2002). Research has also revealed that many preschool teachers consider mathematics and science as difficult to teach, because they are not always prepared to teach domain-specific knowledge, apart from literacy, to young children (Brenneman et al. 2016; Murphy et al. 2018). There is a direct link between teachers' attitudes and behaviour (Aldemir \& Kermani 2017; Hedges \& Cullen 2005a, 2005b) and children's opportunities to learn, as well as a positive correlation between the amount of mathematics and science-related talk a teacher engages in and the development of children's knowledge (Aldemir \& Kermani 2017). The preschool teachers' backgrounds, their years of teaching experience, their level of education and professional qualifications determine the quality of engagement in mathematics and science activities in the preschool classrooms (Piasta et al. 2014).

This study also observes a discrepancy in the score of PCK between the teachers from Gavle and Gaborone, which could be attributed to the latter's lack of ECE training. The teachers in Gaborone had SMK of the science and mathematics concepts but lacked knowledge about how to teach the same concepts using developmentally appropriate methods at the preschool level. In order to 
support children in their explorations and problem-solving, and to use concepts effectively and correctly, preschool teachers need to make didactical considerations in the preschool's daily activities. Without any training in how to do that, they will fail to teach the concepts in a meaningful way and may even avoid engaging in mathematics and science teaching in their classrooms. They are also likely to find it difficult to communicate mathematical and scientific concepts in ways that children can understand, practise developmentally appropriate activities, document the children's performances and perhaps will also be unable to decide what children should learn at their various developmental stages.

The findings of this study endorse that the deployment of trained preschool teachers is critical and that engaging primary school teachers in preschools should ideally be avoided if the aim is to develop children's interest, knowledge and skills in mathematics and science (Chesloff 2013; Clements \& Sarama 2009; Fernandez 2014; Fleer et al. 2014; Inan 2010; Lee 2017; McCray 2008; Sylva et al. 2010; Wood \& Hedges 2016). An awareness of how to deliver content in an effective, interesting and understandable way to young children and how to give children appropriate mathematics and science process skills at the right time is essential (Inan 2010). The SMK of the content is also crucial, but if teachers do not know how to make the content simpler and developmentally appropriate, the result shows that they will be unable to help children understand and engage in classroom activities related to science and mathematics. They will therefore find it difficult to organise mathematics and science activities in play-based and resourceful ways and to help the children participate in practical experiments, explorations and observations in creative, imaginative and interesting ways.

Preschool teachers need to know how to deal with concepts and make them understandable for children and to provide developmentally appropriate practices. In Gavle, about a two-thirds of the teachers used documentation (e.g. using recordings and photos) to make the children's experiences and learning processes visible in the daily activities. The specialised, professional ECE training that they received perhaps made this easier for them.

Preschool teachers should be aware of children's critical conditions for learning and use didactical strategies to make the right conditions available to them (Wood \& Hedges 2016). They also need to be able to see the link between the content (subjects) and the educational activities, create different opportunities for children's learning and use subject didactics that are most appropriate for young children (Chesloff 2013; Grossman 1990; Lee 2017; Shulman 1986b). Pedagogical knowledge, didactical strategies like observation, documentation and reflection for highlighting concepts, actively listening to children and responding accordingly are all crucial aspects of PCK in a preschool context (Fu 2010; Lee 2017; Seitz 2008).
Similarly, preschool teachers need knowledge in order to give children opportunities, observe them and guide the mathematics and science activities so that they are carried out effectively (Campbell et al. 2018; Chesloff 2013; Hunting et al. 2012). The use of physical hands-on material for understanding and developing SMK and PCK in ECE is important for preschool teachers and helps them to teach mathematics and science in preschools effectively (Gallenstein 2004; Moomaw 2011). With PCK and SMK, teachers can interact with children productively, share their thinking, reflect with them on the content (Siraj-Blatchford et al. 2002) and make developmentally appropriate and contextual judgements.

The professional development of preschool teachers enables them to observe children's activities, ask questions about the content and acquire knowledge about children's earlier experiences, include mathematics and science learning opportunities in their classrooms and integrate them into their daily routines. Teachers with specialised training in ECE content and pedagogy can scaffold children's mathematics and science thinking based on the children's prior experiences and informal knowledge (New Jersey Department of Education 2014).

Play is a common way of creating learning situations in preschools. As preschool teaching is often conducted in the form of play (Cohrssen et al. 2013; Fleer 2015; Van Oers 2010; Vogt et al. 2018), PCK in this area is important. Preschool teachers can create learning environments using play, where children can explore and carry out experiments. A lack of ECE training limits the preschool teachers' PCK, imagination and creativity and thus prevents them from appreciating the significance of varied instructional strategies. Through specialised and professional ECE training, teachers can be encouraged to engage in reflective practices that enable them to generate pedagogical knowledge (Wood \& Bennett 2000).

It can therefore be assumed that specialised ECE training provides preschool teachers with PCK, makes them aware of their own experiences, provides them with the necessary knowledge to recognise children's competences, comprehensions and abilities and enables them to fruitfully interact with children during the teaching or learning process. An understanding of a subject's concepts, pedagogical strategies and didactical considerations can help them plan indoor and outdoor activities efficiently. Their developed PCK can also enable them to understand children's developmental stages, needs and requirements and act accordingly.

\section{Professional early childhood education teacher training programmes}

The role of teacher educators is challenging, in that they need to identify with teachers' ideas, beliefs and knowledge about teaching (Aldemir \& Kermani 2017) and put a process 
in place that will influence how they teach in the classroom and enhance their knowledge base (Cassidy \& Buell 1995; Davis \& Simtt 2003). According to Cassidy and Buell (1995), trainee teachers who take part in ECE training courses gain knowledge and can develop their teaching and classrooms appropriately after the training. This is also in line with the finding of Lee (2017), who argues that teachers with a master's degree in ECE have a higher PCK than teachers with a bachelor's degree. In research conducted by Wood and Bennett (2000), the participant teachers' PCK increased with education in ECE. However, the question is, 'do they apply the knowledge, theories and innovative models of teaching or learning that they have acquired through ECE training?' Research shows that professional training often has little effect on their firmly held beliefs and conceptions about teaching (Finson, Thomas \& Pedersen 2006; Korthagen, Loughran \& Russel 2006; Pajares 1992; Whitcomb 2003; Wideen, Mayer-Smith \& Moon 1998). It is also the case that teachers who complete a science teacher training programme aimed at reform-minded instruction never implement what they have learnt in the classroom, but continue with their earlier classroom practices (Abell et al. 2009).

It is thus important to introduce special review measures that not only ensure the acquisition of the relevant knowledge and skills, but also enable trained teachers to use them in their classrooms. A sound ECE teacher training curriculum with course work, a rich and relevant content, coupled with practical and experiences of fieldwork in both mathematics and science, with the minimum required hours of in-service training and an assurance of receiving continuous, appropriate, quality training, is mandatory for preschool teachers (Brenneman et al. 2016). Short courses and workshops need to be introduced that could provide models that allow teachers to explore the SMK and PCK of mathematics and science at length and that facilitate their understanding of how children learn concepts in a developmentally appropriate way.

One of the limitations of this study is the measurement of preschool teachers' knowledge with regard to SMK and PCK in mathematics and science from two different countries and the discrepancies in the respective educational systems, steering documents, and cultural, socio-economic and political issues. The sample in this study provided a result that is not possible to generalise to other settings. A further limitation of the study is the fact that the Swedish teachers taught in their mother tongue, whereas the Botswanan teachers taught in their second language of English. So, in Botswana, both the teachers and the children worked with the mathematical and science content and contexts in their second language. On the other hand, in many Swedish preschools, there are families who are migrants with mother tongues other than Swedish, which means that the results need to be understood and discussed with care.

\section{Conclusion}

The findings show that preschool teachers' knowledge bases need to include knowledge about a play-based approach and how to make didactic choices in activities and spontaneous situations so that they are teachable. The findings also show the importance of a framework for specialised and professional ECE training to acquire SMK and PCK that could contribute to the teachers' knowledge bases and practices in the teaching of mathematics and science in the preschool. Early children education teachers' educational experiences, specialised and professional training profiles, knowledge bases and the SMK and PCK of teaching science and mathematics can perhaps minimise the constraints and challenges faced in ECE classrooms. Attention also needs to be given to upgrading the SMK and PCK and other skills and competencies of preschool teachers on a regular basis. The introduction of short courses, workshops and the provision of support material are crucial and would give preschool teachers the necessary knowledge and confidence to teach mathematics and science in their preschool settings.

The essence of the study is that preschool teachers need training in ECE and that primary school teachers should not be employed to teach very young children.

\section{Acknowledgements}

This article is one of the outcomes of a collaborative project (2012-2014) between the University of Gavle (UoG) and the University of Botswana (UB) entitled 'PCK and SMK in Mathematics and Science in Early Childhood Education (ECE)' The authors of this article were the country coordinators (Botswana and Sweden) for the project. Dr. Maria Tsamaase and Ms Grace Seetso from Botswana participated in the data collection and the data analysis and have co-authored other articles relating to Botswana with the primary author of this article. From Sweden, Dr Annie Hammarberg and Ms Inger Hedman (lecturer) also took part in the data collection and the analysis, and Mr Göran Nordström (lecturer) managed the workshops. Ms Lottie Finnstrom, from University of Gavle, Sweden was the overall project leader.

\section{Competing interests}

The authors declare that they have no financial or personal relationships that may have inappropriately influenced them in writing this article.

\section{Authors' contributions}

$\mathrm{K}$. Bose as the first author has done the main part of the manuscript, and K. Bäckman as second author contributed to all parts of the manuscript. 


\section{Funding information}

The project was jointly funded and supported by the Swedish International Development Cooperation Agency (SIDA) and the Office of Research and Development (ORD).

\section{Data availability statement}

Data sharing is not applicable to this article as no new data were created or analysed in this study.

\section{Disclaimer}

The views and opinions expressed in this article are those of the authors and do not represent the official policy or positions of the institutions or funders.

\section{References}

Abell, S.K., Park Rogers, M.A., Hanuscin, D.L., Lee, M.H. \& Gagnon, M.J., 2009, 'Preparing the next generation of Science teacher educators: A model for developing PCK for teaching Science teachers', Journal of Science Teacher Education 20(1), 77-93. https://doi.org/10.1007/s10972-008-9115-6

Aldemir, J. \& Kermani, H., 2017, 'Integrated STEM curriculum: Improving educational outcomes for head start children', Early Child Development and Care 187(11), 1694-1706. https://doi.org/10.1080/03004430.2016.1185102

Brenneman, K., Stevenson-Boyd, J. \& Frede, E.C. (eds.), 2009, Mathematics and Science in preschool: Policy and practice, viewed from https://www.researchgate. net/publication/255660021_Mathematics_and_Science_in_Preschool_Policy_ and_Practice.

Brenneman, K., Stevenson-Boyd, J. \& Frede, E.C., 2016, 'Math and science in preschool: Policies and practice', Preschool Policy Brief, ERIC, Institute of Education Sciences 19, viewed from https://eric.ed.gov/?id=ED534142.

Campbell, C., Speldewinde, C., Howitt, C. \& MacDonald, A., 2018, 'STEM practice in the early years', Creative Education 9(1), 11-25. https://doi.org/10.4236/ ce.2018.91002

Cassidy, I. \& Buell, M., 1995, 'The effect of education on child care teachers' beliefs and classroom quality: Year one evaluation of the TEACH early childhood associate degree scholarship program', Early Childhood Research Quarterly 10(2), 171-183. https://doi.org/10.1016/0885-2006(95)90002-0

Cohrssen, C., Church, A., Ishimine, K. \& Tayler, C., 2013, 'Playing with Maths: Facilitating the learning in play-based learning', Australasian Journal of Early Childhood 38(1), 95-99. https://doi.org/10.1177/183693911303800115

Chesloff, J.D., 2013, 'Why STEM education must start in early childhood', Education Week 32(23), 27-32.

Clements, D.H. \& Sarama, J., 2009, Learning and teaching early math: A learning trajectories approach, Springer, New York, NY.

Cohen, L., Manion, L. \& Morrison, K., 2011, Research methods in education, 7th edn., Routledge, London.

Creswell, J.W., 2003, Research design: Qualitative, quantitative, and mixed methods approaches, 2nd edn., Sage, Thousand Oaks, CA.

Darling-Hammond, L., 2000, 'How teacher education matters', Journal of Teacher Education 51(3), 166-173. https://doi.org/10.1177/0022487100051003002

Davis, B. \& Simtt, E., 2003, 'Understanding learning systems: Mathematics education and complexity science', Journal for Research in Mathematics Education 34(2), 137-167. https://doi.org/10.2307/30034903

Essa, E.L., 2013, Introduction to early childhood education, Wardsworth, Belmont, CA.

Fernandez, C., 2014, 'Knowledge base for teaching and pedagogical content knowledge (PCK): Some useful models and implications for teachers' training', Problems of education in the 21st century 60, 79-100.

Finson, K.D., Thomas, J. \& Pedersen, J.E., 2006, 'Comparing science teaching styles to students' perceptions of scientists', School Science and Mathematics 106(1), 8-15. https://doi.org/10.1111/j.1949-8594.2006.tb18066.x

Fleer, M., 2014, Theorising play in the early years, Cambridge University Press, New York, NY.

Fleer, M., 2015, 'Pedagogical positioning in play - Teachers being inside and outside of children's imaginary play', Journal of Early Child Development and Care 185(11-12), 1801-1814. https://doi.org/10.1080/03004430.2015.1028393

Fleer, M., Gomes, J. \& March, S., 2014, 'Science learning affordances in preschool environments', Australasian Journal of Early Childhood 39(1), 38-48. https://doi. org/10.1177/183693911403900106

Fu, V.R., 2010, Learning and teaching in preschool, viewed January 2016, from http:// www.pbs.org/teachers/earlychildhood/articles/learning.html.

Gallenstein, N.L., 2004, 'Creative discovery through classification (early childhood corner)', Teaching Children Mathematics 11(2), 103-108.
Garbett, D., 2003, 'Science education in early childhood teacher education: Putting forward a case to enhance student teachers' confidence and competence' Research in Science Education 33(4), 467-481. https://doi.org/10.1023/ Research in Science Education
$\mathrm{B}:$ RISE.0000005251.20085.62

Gasteiger, H., Bruns, J., Benz, C., Brunner, E. \& Sprenger, P., 2020, 'Mathematical pedagogical content knowledge of early childhood teachers: A standardized situation-related measurement approach', ZDM Mathematics Education 52, 193-205. https://doi.org/10.1007/s11858-019-01103-2

Grossman, P., 1990, The making of a teacher: Teacher knowledge and teacher education, Teachers College Press, Teachers College, Columbia University, New York, NY.

Hedges, H. \& Cullen, J., 2005a, 'Meaningful teaching and learning: Children's and teachers' content knowledge', ACE Papers 16, 11-24.

Hedges, H. \& Cullen, J., 2005b, 'Subject knowledge in early childhood curriculum and pedagogy: Beliefs and practices', Contemporary Issues in Early Childhood 6(1), 66-79. https://doi.org/10.2304/ciec.2005.6.1.10

Hunting, R., Mousley, J. \& Perry, B., 2012, 'A study of rural preschool practitioners' views on young children's mathematical thinking', Mathematics Education views on young children's mathematical thinking', Mathematics Ed
Research Journal 24, 39-57. https://doi.org/10.1007/s13394-011-0030-3

Inan, H.Z., 2010, 'Examining pre-school education teacher candidates' content knowledge and pedagogical content knowledge', Educational Sciences: Theory \& Practice 10(4), 2309-2323.

Kallery, M. \& Psillos, D., 2001, 'Preschool teachers' content knowledge in Science: Understandings of elementary science concepts and of issues raised by children's questions', International Journal of Early Years Education 9(3), 165-177. https:// doi.org/10.1080/09669760120086929

Klibanoff, R., Levine, S., Huttenlocher, J., Vasilyeva, M. \& Hedges, L., 2006, 'Preschool children's mathematical knowledge: The effect of teacher "math talk"', Developmental Psychology 42(1), 59-69. https://doi.org/10.1037/0012-1649.42.1.59

Korthagen, F., Loughran, J. \& Russell, T., 2006, 'Developing fundamental principles for teacher education programs and practices', Teaching and Teacher Education 22(8), 1020-1041. https://doi.org/10.1016/j.tate.2006.04.022

Lee, J.E., 2017, Preschool teachers' pedagogical content knowledge in mathematics', International Journal of Early Childhood 49, 229-243. https://doi.org/10.1007/ s13158-017-0189-1

MacDonald, A., Huser, C. \& Sikder, S., 2019, 'Effective early childhood STEM education: Findings from the little scientists evaluation', Early Childhood Education Journal 48, 353-363. https://doi.org/10.1007/s10643-019-01004-9

Mathangwane, T.J. (ed.), 2011, Trends in International Mathematics and Science Study (TIMSS), Botswana Examinations Council, Gaborone.

McCray, J.S., 2008, Pedagogical content knowledge for preschool mathematics: Teacher knowledge and math-related language contribute to children's learning, Erikson Institute, Chicago, IL.

McCray, J.S. \& Chen, J-Q., 2012, 'Pedagogical content knowledge for preschool Mathematics: Construct validity of a new teacher interview', Journal of Research in Childhood Education 26(3), 291-307. https://doi.org/10.1080/02568543.2012. 685123

Moomaw, S., 2011, Teaching Mathematics in early childhood, Brookes Publishing Company, Baltimore, MD.

OECD, 2019, PISA 2018 Results (Volume I): What students know and can do, PISA OECD Publishing, Paris. https://doi.org/10.1787/5f07c754-en

Pajares, F., 1992, 'Teachers' beliefs and educational research: Cleaning up a messy construct', Review of Educational Research 62, 307-332. https://doi. org/10.3102/00346543062003307

Piasta, S.B., Pelatti, C.Y. \& Miller, H.L., 2014, 'Mathematics and Science learning opportunities in preschool classrooms', Early Educational Development 25(4), 445-468. https://doi.org/10.1080/10409289.2013.817753

Republic of Botswana, 2011, Population and housing census: Preliminary results brief, Ministry of Finance and Development Planning, Central Statistics Office, Gaborone.

Republic of Botswana, 2015a, Education \& training sector strategic plan (ETSSP 2015-2020), Government Printers, Gaborone.

Republic of Botswana, 2015b, National curriculum and assessment framework, Government Printers, Gaborone, Botswana.

Seitz, H., 2008, 'The power of documentation in the early childhood classrooms', National Association for Education of Young Children: Young Children 63(2), 88-93.

Shulman, L., 1986a, 'Those who understand: Knowledge growth in teaching', EducationalResearcher15(4), 4-14.https://doi.org/10.3102/0013189X015002004

Shulman, L., 1986b, 'Knowledge and teaching: Foundations of the new reform', Journal Harvard Education Review 57(1), 1-22. https://doi.org/10.17763/ haer.57.1.j463w79r56455411

Shulman, L., 2015, 'PCK: Its genesis and exodus', in A. Berry, P. Friedrichsen \& J. Loughran (eds.), Re-examining pedagogical content knowledge in Science education, Routledge, New York, NY.

Siraj-Blatchford, I., Sylva, K., Muttock, S., Gilden, R. \& Bell, D., 2002, Researching effective pedagogy in the early years, Research report No 356, DfES, HMSO, effective
London.

Sylva, K., Melhuish, E., Sammons, P., Siraj-Blatchford, I. \& Taggart, B., 2010, Early childhood matters. Evidence from the effective pre-school and primary education project, Routledge, London.

Smith, L.T., 1999, 'Decolonizing methodologies: Research and indigenous peoples', Social Policy Journal of New Zealand 17, 214-217.

The Swedish National Agency for Education, 2010, Curriculum for preschool Lpfö 98, new, rev. edn., The National Agency for Education, Stockholm. 
The Swedish National Agency for Education, 2016, TIMSS 2015 (The Trends in International Mathematics and Science Study), The National Agency for Education, Stockholm.

The Swedish National Agency for Education, 2018, Curriculum for preschool Lpfö18, The National Agency for Education, Stockholm.

Tashakkori, A. \& Teddlie, C., 2009, Foundations of mixed methods research integrating quantitative and qualitative approaches in the social and behavioral sciences, Sage, Thousand Oaks, California.

Vallberg, R., 2006, 'Early childhood curricula in Sweden from the 1850 s to the present', International Journal of Early Childhood 1, 77-98. https://doi.org/10.1007/ BF03165979

Van Oers, B., 2010, 'Emergent mathematical thinking in the context of play', Educationa Studies in Mathematics 74, 23-37. https://doi.org/10.1007/s10649-009-9225-x

Vogt, F., Hauser, H., Stebler, R., Rechsteiner, K. \& Urech, C., 2018, 'Learning through play - Pedagogy and learning outcomes in early childhood mathematics', European Early Childhood Education Research Journal 26(4), 589-603. https://doi. org/10.1080/1350293X.2018.1487160
Whitcomb, J.A., 2003, 'Learning and pedagogy in initial teacher preparation', in W.M. Reynolds \& G.E. Miller (eds.) \& I.B. Weiner (Editor in chief), Handbook of psychology, Volume 7: Educational psychology, pp. 533-556, John Wiley \& Sons, Inc, New York.

Wideen, M., Mayer-Smith, J. \& Moon, B., 1998, 'A critical analysis of the research on learning how to teach: Making the case for ecological perspective on inquiry', Review of Educational Research 68(2), 130-178. https://doi.org/10.3102/0034 Review of Educatic

Wiersma, E.W. \& Jurs, S.G., 2009, Research methods in education: An introduction, 9th edn., Pearson, Boston.

Wood, E. \& Bennett, N., 2000, 'Changing theories, changing practice: Exploring early childhood teachers' professional learning', Teaching and Teacher Education 16(5-6), 635-647. https://doi.org/10.1016/S0742-051X(00)00011-1

Wood, E. \& Hedges, H., 2016, 'Curriculum in early childhood education: Critical questions about content, coherence, and control', The Curriculum Journal 27(3), 387-405. https://doi.org/10.1080/09585176.2015.1129981 